\title{
FOREWORD TO THE EDITION
}

\section{By GEORGE A. KIRAZ}

The primary objective of this edition is twofold: to provide a reliable text for scholars and students who are looking for a fully vocalized Syriac text, and to make available to religious communities, for whom this text is sacred, an English translation that can be used in various religious and cultural settings. As such, one had to navigate carefully between rigid scholarly principles and practical editorial choices.

\section{Making of the Text}

The current edition provides a West Syriac version of the 1887-91 Peshițta Mosul text. ${ }^{1}$ While the Mosul text was prepared based on second millennium manuscripts, its text is substantially attested by manuscripts belonging to the first millennium. As ancient MSS are hardly vocalized, our text relies on the vocalization of the Mosul edition. In addition to full vocalization, our text is supplemented with complete Rukkākhā and Quššàyā pointing and other orthographic markings, keeping in mind the general orthographic principles adopted by Pusey and Gwilliam in their 1901 Tetraeuangelium. ${ }^{2}$ Hence, while the consonantal tier is substantially ancient, the vocalism and orthographic tiers are quite late.

As the Mosul edition did not fully mark Rukkākhā and Quššāyā, these points were added and a regular expression ${ }^{3}$ was applied to the text to

${ }^{1}$ Clemis Joseph David (ed.), The Syriac Bible According to the Mosul Edition, 3 volumes, with an introduction by Sebastian P. Brock (Piscataway, NJ, 2010), a reprint of the Mosul 1887-91 edition titled IA

2 P. E. Pusey and G. H. Gwilliam, Tetraenangelium Sanctum, the Fourfold Holy Gospel in the Peshitta Syriac Version with Critical Apparatus, with an introduction by Andreas Juckel (Piscataway, NJ, 2003), a reprint of the 1901 edition.

${ }^{3}$ In computing, a regular expression provides a mechanism with which strings of text can be matched with a search criterion. In most notations, a bracket expression matches a single character inside that bracket (e.g., [ab] matches a single $a$ or $b$ ). The exclamation mark denotes negation. Hence, the expression [bgdkpt][!RQ] (where $\mathrm{R}$ and $\mathrm{Q}$ represent the 
ensure that all bgädkpät letters are marked. When the consonantal orthography, and in many cases the vocalic orthography, of East and West Syriac diverged, use was made of Lee's 1823 edition $^{4}$ as well as linguistic resources including Audo, ${ }^{5}$ Brockelmann, ${ }^{6}$ Margoliouth, ${ }^{7}$ and Smith. ${ }^{8}$ As for Rukkākhā and Quššāyā pointing, analogies were made internally within other Mosul readings, and externally with the Pusey and Gwilliam New Testament text, making use of my Concordance 9 as a tool and the guidelines presented in my introduction to spirantization. ${ }^{10}$ In some cases, Mašlmānūthā MSS ${ }^{11}$ (hereinafter, Maš.) were consulted to determine Peal vs. $\mathrm{Pa}^{\text {ee }}$ el fricatization marking.

The Mbațțānā and Marhțānā were added systematically following current orthographic conventions, but the Mhaggyānā, Nāgudā, and Mțappyānā, all ubiquitous in the Mosul text, were removed as they are alien to West Syriac orthography. ${ }^{12}$

\section{Orthographic Diversions from Mosul}

In terms of the consonantal tier, the present text differs orthographically from the Mosul text in two ways. Firstly, it intentionally replaces early Syriac orthographic conventions, most of which are also preserved in the East Syriac Mosul text, with West Syriac ones. ${ }^{13}$ As for the vocalic tier, the present text differs from the Mosul text in a number of ways.

Rukkākhā and Quššāyā points, respectively) will match a single bgädkpāt letter that is not followed by a Rukkākhā or Quššāyā point. When this search fails, all bgādkpāt letters have been pointed (regardless of accuracy of course).

4 S. Lee, Vetus et Novum Testamentum Syriace (London, 1823).

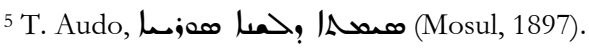

${ }^{6}$ C. Brockelmann, Lexicon Syriacum (2nd ed., 1928).

${ }^{7}$ J. P. Smith (Mrs. Margoliouth), A Compendious Syriac Dictionary Founded upon the Thesaurus Syriacus (Oxford, 1903).

8 P. Smith, Thesaurus Syriacus (Oxford, 1879-1901).

${ }_{9}$ G. A. Kiraz, A Computer Generated Concordance to the Syriac New Testament, 6 volumes (Leiden, 1993).

10 G. A. Kiraz, Introduction to Syriac Spirantization, Rukkâknâ and Quššâyâ (Losser, 1995).

11 We used Vat. Syr. 152 and BL Add. 12,178.

12 On these symbols, see C. J. David, Grammaire de la Langue Araméenne, 2 volumes, (Mosul, 2nd ed., 1896) \$62, \$67; G. Kiraz, Türrās Mamllā, A Grammar of the Syriac Language, Volume I Orthography (Gorgias Press, 2012) \$\$205-208.

13 On orthography, see L. Van Rompay, 'Some Preliminary Remarks on the Origins of Classical Syriac as a Standard Language. The Syriac Version of Eusebius of Caesarea's Ecclesiastical History', in G. Goldenberg and S. Raz (eds.), Semitic and Cushitic Studies 
E. Syr. ' was generally converted to the corresponding W. Syr. except in lexemes where the E. and W. Syriac orthographies vary. In the case of $b d w l$ prefixes attaching to $l_{0}$ os , Mosul always uses an E. Syr. while here a W. Syr. ${ }^{\prime}$ is used.

E. Syr. 'ं was generally converted to W. Syr. except when followed by $\bullet$ in which case it became $\tilde{F}$. This also applies to nominal forms when followed by an enclitic demonstrative pronoun.

E. Syr. ' was generally converted to W. Syr. except in lexemes where the E. and W. orthographies vary.

E. Syr. ${ }^{\circ}$ was mapped to either or depending on the phonological, morphological or lexical context.

E. Syr. ־ was converted to W. Syr. •, while E. Syr. o and o were collapsed into W. Syr. ॰. The choice was made to place the vowel on the consonant preceding the matres lectionis.

The Mbațțānā was applied in the present text following the Pusey and Gwilliam tradition but with further extensions following contemporary orthographic conventions.

The following readings in Mosul were rejected:

Here

Susanna 2

Susanna 29

Susanna 36

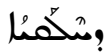

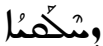

Lif

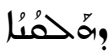

Susanna 63

Esther 1:10

Esther 1:14

Esther 1:14

Esther 1:14

Esther 3:9

Esther 6:1

Esther 9:7

Esther 9:8

Esther 9:8

Esther 9:9

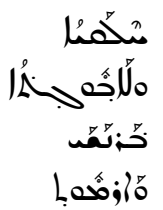

高
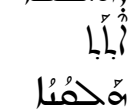

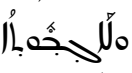

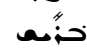

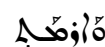

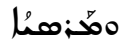

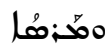
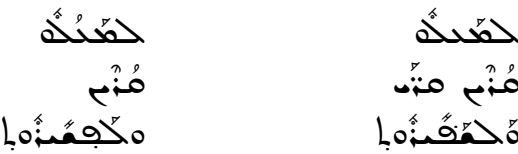

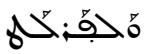

o

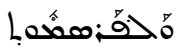
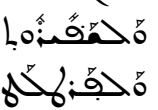

ơ

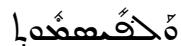

(Wiesbaden, 2004), 70-89; S. P. Brock, 'Some Diachronic Features of Classical Syriac', in M. F. J. Baasten and W. Th. Van Peursen (eds.), Hamlet on the Hill. Semitic and Greek Studies Presented to Professor T. Muraoka on the Occasion of his Sixty-Fifth Birthday (Louvain, 2003), 95111. 
Judith $4: 4$

Judith 6:15

Judith 8:9

Judith $8: 32$

Judith $14: 3$

Judith 14:5

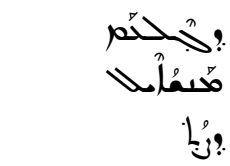

'?
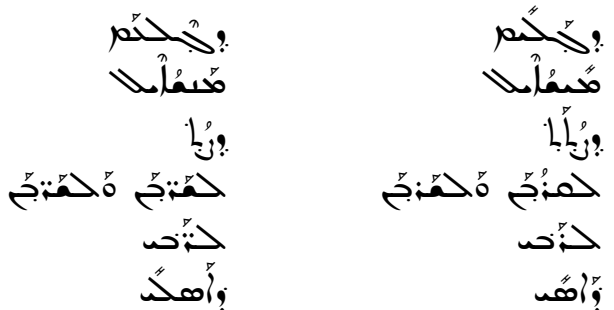

We made some consonantal changes to proper nouns per Mash MSS (vowel changes are not listed):

\section{Text Organization}

The division of the text into chapters and verses is a recent Western phenomenon. Early manuscripts divided the texts into chapters, called in

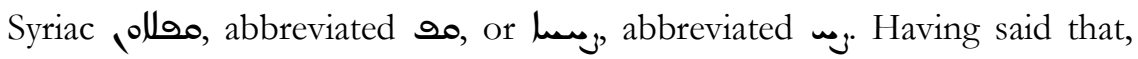
ancient manuscripts do not always follow a systematic approach in these chapter divisions. The present text follows the recent Western division of chapters, naming each chapter in Syriac ollo. Ancient Syriac chapter divisions are given in the outer margin preceded by the abbreviation $\mathbf{n}_{\mathrm{n}}$ for كُمُسُ (they correspond to Roman numerals in the English translation). These were provided by Adam Kane and Joshua Falconer. The numbers are based on Ms Diyarbakir 1/1 (HMML: DIYR 00002; Peshitta Institute siglum: 15a3). The present edition follows the versification of Paul A. de Lagarde (1861). Ancient manuscripts vary in the application of punctuation marks. The punctuation presented here follows the Mosul punctuation faithfully.

\section{Acknowledgements}

Andreas Juckel, my co-editor in the Surath Kthob series, played a major role in setting the textual policies of the edition. I am personally grateful to my wife Christine and three children: Tabetha Gabriella, Sebastian Kenoro, and Lucian Nurono.

It is hoped that the current edition will be a motivation for further texts and translations of the Syriac Biblical tradition, and will stimulate the use of the Peshițta in educational and religious settings. 